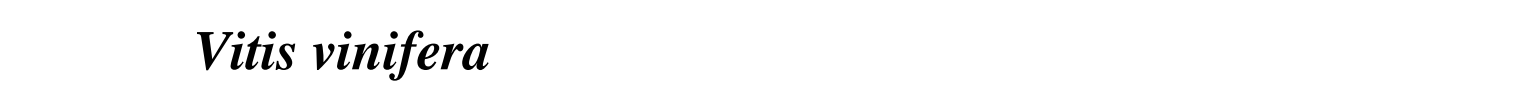

\section{باسحوق IBA في تهسبن صفلت النمو الجنري}

\author{
ليلاد هاني إلسماعلى الملاف \\ قصم البستة وهنهسة الحداثق \\ كلية الزراعة والغابلت \\ جلمعة الموصل \\ (تاريخ الاستلام 17 / 2 / 2010 ؛ تاريخ القبول 26 /4 / 2010)
}

\section{المالغص}

تضمنت الدرلسة معرفة تأثير لُوال العثل (عفل ذات عينين وعثل ذات ثلاث عيون) وثلاثة

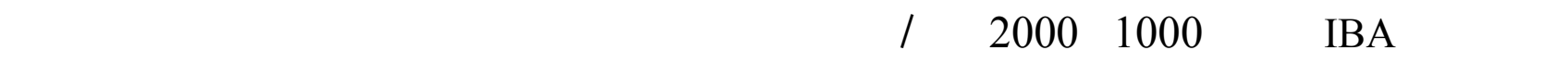

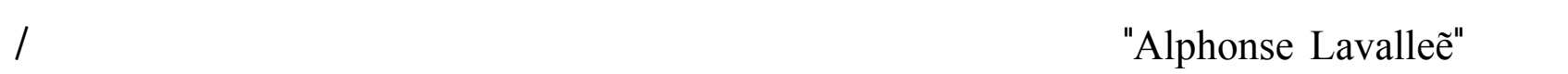

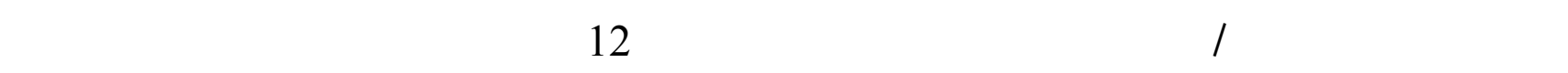
فقوق العظل ذات ثلاث عيون معنويا بجمبع صفلت النمو الجذري والخضري على العثل ذات العين العينين

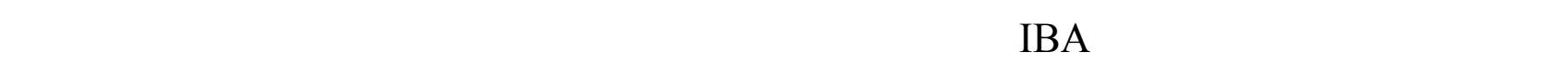

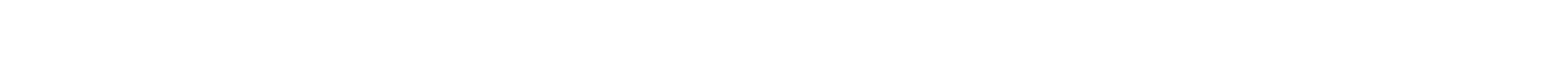
معنوية بين جمبع الترلكيز، أعلى نسبة لتجذير العثل 100\% قم الحصول عليها من التدلخل بين العثل ذات 3

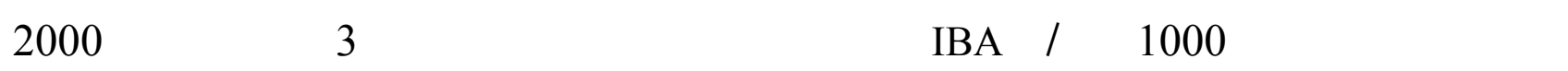

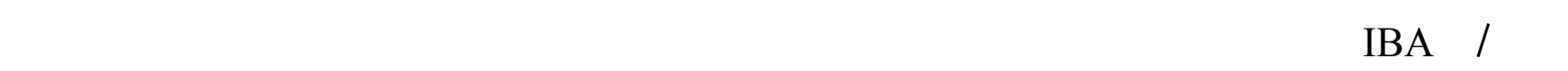
الحيثة وبلغت 20,10 جذرا و8,06سم و15,77 ورقة و2,27 نمو و1,721 1سم على التوالي .

الكاملت الدالة : - نسبة التجنير ، عزل ششبية ، أندط حاهض البيوترك ، عدد العيون ، العب. 
أياد هاني إlٕماعبل العلاف

\title{
The Interaction Effect Among the Existing Eyes Numbers of the Cuttings Grape and Treatment by IBA Powder in the Improvement of the Root Growth
}

\author{
Ayad H. Esmaeel Al-Allaf \\ Departmen of Horticulture and Land Scape Design \\ College of Agriculture and Forestry \\ Mosul University
}

\begin{abstract}
This research was conducted in the plastic houses at Horticulture Dep. College of Agriculture and Forestry Mosul University, Iraq, to study the effect of three concentrations of auxin IBA 0,1000 and $2000 \mathrm{mg} / \mathrm{L}$ and number of eyes on cuttings with two or three eyes on rooting and growth parameters of hardwood Grape cuttings. After Twelve weeks from culture date cuttings examined for rooting and vegetative growth. Cuttings with three eyes significantly show increase in all parameters as compared with cuttings with two eyes(rooting percentage, root number and length, fresh and dry root weight, new shoots, new leaves, number and length of new shoots, fresh and dry vegetative weight parameters, at the same time the two concentrations of auxin IBA 1000 and $2000 \mathrm{mg} / \mathrm{L}$ increased significantly all rooting and vegetative parameters, except the percentage of rooting and number of new shoots. However the interaction treatment (cutting with three eyes +1000 $\mathrm{mg} / \mathrm{L}$ IBA) gave a $100 \%$ of rooting percentage, but the highest average of ( root number and length, new leaves, number and length of new shoots) resulted from cutting with three eyes treated with $2000 \mathrm{mg} / \mathrm{L}$ IBA value which reached $20.10,8.06 \mathrm{~cm}, 15.77,2.27$ and $11.72 \mathrm{~cm}$ respectively .
\end{abstract}

Key words: Percentage rooting, Hardwood cuttings, IBA, Number of eyes, Grape 